\title{
Pepsin and Laryngeal and Hypopharyngeal Carcinomas
}

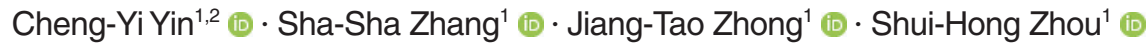 \\ ${ }^{I}$ Department of Otolaryngology, The First Affiliated Hospital, College of Medicine, Zhejiang University, Hangzhou; \\ ${ }^{2}$ Department of Otolaryngology, The First People's Hospital of Huzhou City, Zhejiang, China
}

Laryngeal and hypopharyngeal carcinomas are common malignant tumors of the head and neck, and the incidence of both is increasing. Laryngopharyngeal reflux refers to the retrograde flow of gastric contents into the larynx, oropharynx, and/or nasopharynx. It remains controversial whether laryngopharyngeal reflux is a risk factor for laryngeal and hypopharyngeal cancers. The refluxing substances mainly include hydrochloric acid, pepsin, and occasionally bile acids and bile salts, as well as bacteria that colonize the gastrointestinal tract. Loss of epithelium in the mucous membrane of the larynx and hypopharynx is thought to be caused by pepsin. Here, we review the relationships between laryngopharyngeal reflux and both laryngeal and hypopharyngeal carcinomas, as well as the significance of pepsin, methods of clinical detection, and the mechanism of carcinogenesis.

Keywords. Pepsin; Laryngopharyngeal Reflux; Laryngeal Carcinoma; Hypopharyngeal Carcinoma

\section{INTRODUCTION}

Laryngeal and hypopharyngeal carcinomas are common malignant tumors of the head and neck. Despite reductions in the rates of smoking and alcohol abuse, the incidence of laryngeal and hypopharyngeal carcinomas is increasing [1-3]. Many studies have shown that tobacco and alcohol are risk factors for laryngeal and hypopharyngeal carcinomas [4-6]. Other risk factors include human papillomavirus, radiation exposure, and laryngopharyngeal reflux (LPR) [7-10]. However, the actual causes remain unclear. LPR has attracted attention as a risk factor for laryngeal and hypopharyngeal carcinomas. In contrast to the esophageal mucosa, the laryngeal and hypopharyngeal mucosa lacks the catalytic enzyme carbonic anhydrase, which produces bicarbonate [9]. Therefore, the laryngeal mucosa has a poor selfprotection capacity and a weak mucosal epithelium, as well as

\footnotetext{
- Received March 28, 2020

Revised July 12, 2020

Accepted July 17, 2020

- Corresponding author: Shui-Hong Zhou

Department of Otolaryngology, The First Affiliated Hospital, College of Medicine, Zhejiang University, 79 Qingchun Road, Hangzhou 310003, China

Tel: +86-571-87236894, Fax: +86-571-87236895

E-mail: 1190051@zju.edu.cn
}

poor adaptability to chemical stimuli (e.g., gastric acid and pepsin) and sensitivity to damage caused by LPR stimulation [9-11]. Similar findings have been reported for the hypopharynx $[8,12]$.

Pepsin is mainly synthesized by the major gastric mucosal cells in the form of pepsinogen A, then cleaved in the acidic environment of the stomach to produce the endopeptidase, pepsin, which decomposes protein molecules into smaller peptides. Pepsin exerts its proteolytic activity by twisting and folding the structure of the substrate polypeptide chain [13]. Pepsin has been shown to induce cell damage, inflammation, and tumorigenesis. Herein, we review the association of pepsin with laryngeal and hypopharyngeal carcinomas.

\section{ASSOCIATION OF LPR WITH LARYNGEAL AND HYPOPHARYNGEAL CARCINOMAS}

Since the mid-1980s, patients with laryngeal carcinoma who neither drink alcohol nor smoke have been reported to exhibit an elevated incidence of gastroesophageal reflux [14]. Some authors reported a higher prevalence of reflux in patients with laryngeal cancer $[15,16]$. This has prompted further studies of the association between laryngeal carcinoma and LPR [17-29].

Although limited to differences between lower esophageal

Copyright @ 2021 by Korean Society of Otorhinolaryngology-Head and Neck Surgery.

This is an open-access article distributed under the terms of the Creative Commons Attribution Non-Commercial License (https://creativecommons.org/licenses/by-nc/4.0)

which permits unrestricted non-commercial use, distribution, and reproduction in any medium, provided the original work is properly cited. 
gastroesophageal reflux disease (GERD) and laryngeal pharyngeal reflux disease (LPRD), most studies of the relationship between reflux and laryngeal carcinoma did not distinguish between GERD and LPRD, mainly due to the difficulty in establishing an accurate diagnosis of LPR [20,24]. Therefore, this review uses both terms (LPRD and GERD). There is increasing interest in whether LPRD can induce chronic damage and inflammation of the laryngeal and pharyngeal mucosae, and whether LPRD can induce a final tumorigenic effect on laryngeal and pharyngeal mucosae [17-29]. However, the effects of GERD or LPRD on laryngeal and hypopharyngeal carcinomas remain controversial.

A few studies have reported that GERD and LPRD were not independent risk factors for laryngopharyngeal carcinoma [21, 30-34]. In a prospective case-control study, Geterud et al. [30] reported that there were no significant differences in pathological acid exposure events between patients with laryngeal cancer and volunteers during 24-hour dual-probe $\mathrm{pH}$ monitoring. Nilsson et al. [31] found no significant increase in the risk of laryngeal carcinoma in patients with GERD and LPRD after excluding interference from factors related to alcohol intake. The reason why the correlation between GERD or LERD and laryngopharyngeal carcinoma is controversial may be that most patients with laryngeal malignant tumors have long-term tobacco and alcohol habits. Tobacco and alcohol induce laryngeal cancer and increase the prevalence of reflux in these patients, thereby contributing to bias in the results [31]. Smit et al. [32] performed reflux monitoring of 15 volunteers who underwent 24-hour dual-probe $\mathrm{pH}$ monitoring. They found that the percentage of time with $\mathrm{pH}<4$ was significantly higher in smokers than in nonsmokers, implying that smoking increases the incidence of reflux [32]. Francis et al. [33] reported that GERD and LPRD were not associated with laryngeal cancer, after excluding confounding factors such as tobacco and/or alcohol intake through multivariate logistic regression analysis. Busch et al. [21] reported that GERD did not increase the risks of head and neck cancer, including laryngeal cancer, based on unconditional logistic regression analysis of the correlation between self-reported heartburn and the development of overall head and neck cancer in 1,340 patients. They reported detailed information regarding alcohol and tobacco consumption and controlled for the effects of alcohol and tobacco. Anis et al. [18] also reported that there was no significant association between reflux and the development of laryngeal cancer after excluding alcohol and smoking as con-

\section{H I G H L I G H T S}

- Pepsin promotes the development of laryngeal and hypopharyngeal cancers.

- Multiple mechanisms lead to epithelial cell damage by pepsin.

- Pepsin is a potential therapeutic target for prevention and treatment of laryngeal and hypopharyngeal carcinomas. founding factors.

However, many studies have found LPRD to be associated with malignant tumors of the larynx and pharynx. El-Serag et al. [35] concluded that gastroesophageal reflux or LPR increased the risk of laryngeal carcinoma. Some studies also demonstrated that LPRD or GERD was a risk factor for laryngeal and hypopharyngeal carcinoma after adjusting for factors such as smoking and drinking in multivariate logistic regression analysis [19, $26,27,36]$. In a systematic review and meta-analysis, Parsel et al. [20] found a significant correlation between LPRD and laryngeal malignancies. Thus, the relationship of reflux with laryngeal and hypopharyngeal carcinomas remains controversial. In addition to alcohol abuse and smoking, other possible factors include the lack of uniformity in the diagnostic methods for GERD and/ or LPRD. Some patients were diagnosed using esophagoscopy [37-40], while others were diagnosed using 24-hour dual-probe $\mathrm{pH}$ measurements [41] or based solely on clinical symptoms, management data, and questionnaires [42]. Therefore, caution is necessary when interpreting existing research and conclusions.

\section{PEPSIN AS A MARKER FOR DIAGNOSIS OF LPR AND TEST METHODS}

To date, there is no specific assessment method for diagnosing LPRD. Clinically, symptoms and laryngoscopy are often used as the basis for diagnosis, including the reflux symptom index [43] and laryngeal reflux finding scores [44]. Upper-digestive endoscopy and 24-hour $\mathrm{pH}$ measurements are also widely used to diagnose GERD or LPRD [37-41]. Although the two have similar pathophysiological mechanisms, the laryngeal mucosa is more susceptible to reflux than is the corresponding esophageal mucosa, which renders the laryngeal and hypopharyngeal mucosa vulnerable to backflow $[9-11,45,46]$. Fewer than $20 \%$ of patients with LPRD show signs of esophagitis on upper-gastrointestinal endoscopy, indicating that this method is not sufficiently sensitive for the diagnosis of LPRD [47]. Twenty-four-hour dualchannel $\mathrm{pH}$ measurements dynamically monitor changes in $\mathrm{pH}$ in different parts of the esophagus over 24 hours [41]. Although this is currently the gold standard for diagnosis of GERD, it is an invasive [48,49], time-consuming [50], and expensive test, all of which limit its widespread use and adoption in clinical practice [51]. Therefore, new methods with high specificity and utility for diagnosis are needed.

The pepsin test has good potential for use as a diagnostic method for LPRD. Pepsin is produced only by the chief cells of the stomach, and not by other organs; therefore, the pepsin detected in the larynx and hypopharynx can only be derived from refluxing gastric juice, and can be regarded as a specific marker for LPRD. To date, no consensus exists regarding the ideal detection method, the ideal region for sample selection, or the ideal window for pepsin collection. Accordingly, some groups have ques- 
tioned the reliability of pepsin as a specific marker for LPRD [52,53].

Two methods are currently available for detection of pepsin: the Peptest commercial kit [54,55]; or the use of immunohistochemical (IHC) methods such as enzyme-linked immunosorbent assays, Western blotting, and other protein-based methods [5663]. Peptest is simple, fast, and easy to use, but yields only qualitative results, while protein-based methods allow quantitative measurements, but involve a relatively high price and various requirements that are difficult to satisfy in non-specialized environments. There have also been differences in the selection of samples, with some studies using biopsy specimens [64-66] and others using saliva and sputum $[67,68]$. Jiang et al. [64] performed IHC staining of laryngeal mucosal epithelial tissue test specimens and found that pepsin levels were significantly higher in the laryngeal mucosal epithelium of patients with LPRD than in healthy volunteers $(P<0.01)$. Knight et al. [68] measured pepsin in laryngeal secretion samples by enzyme-linked immunosorbent assay and showed that the pepsin-positive samples had significantly lower pharyngeal $\mathrm{pH}$ than the negative samples of pharyngeal $\mathrm{pH}$ probes. When pepsin measurement results were compared with the results of the diagnosis based on pharyngeal $\mathrm{pH}$ test, the sensitivity and specificity of the pepsin immunoassay for LPRD were $100 \%$ and $89 \%$, respectively. Saritas Yuksel et al. [67] collected saliva from reflux patients and healthy volunteers in a prospective, single-blind study using a pepsin lateral flow device (Peptest commercial kit) to detect pepsin in saliva and the esophagogastric duodenum. The results of microscopic examination by esophagogastroduodenoscopy and acid-free 48hour $\mathrm{pH}$ monitoring indicated that the sensitivity and specificity of the assay were both $87 \%$. Therefore, this test showed high sensitivity and specificity.

Recent research regarding the use of pepsin as a diagnostic marker for laryngeal pharyngeal reflux has indicated that it may be a sensitive and specific diagnostic marker for laryngeal pharyngeal reflux. However, there is a need for further investigation of the detection methods, sample selection, optimal sample collection time, locations of biopsy specimens, and threshold/positive criteria of pepsin detection.

\section{PEPSIN INTHE DEVELOPMENT OF LARYNGEAL AND HYPOPHARYNGEAL CARCINOMAS}

The pathophysiology of LPRD is presumably due mainly to stimulation and damage of the mucosa of the upper respiratory tract by gastric juices (including hydrochloric acid, pepsin, bile acids, and bile salts, as well as bacteria that colonize the gastrointestinal tract) [69-71]. Damage to the esophageal mucosal epithelium in GERD is mainly mediated by acidic fluid, while damage to the laryngopharyngeal mucosal epithelium in LPR is mainly caused by pepsin [72]. Initial studies of LPRD focused on the effects of gastric acid on the mucosa of the upper respiratory tract. However, up to $20 \%$ of patients with acid suppression therapy continue to exhibit symptoms associated with weak acid reflux and non-acid reflux [73]. Despite treatment with proton pump inhibitors (PPIs), mucosal damage can be observed in the upper respiratory tract and digestive tract. Such findings implicate that laryngeal and pharyngeal mucosal damage can occur under nonacidic conditions. Further studies have indicated that pepsin may be responsible for non-acidic damage of laryngeal and pharyngeal mucosae in LPR. Because of the lack of protective mechanisms against reflux in the laryngeal and pharyngeal mucosae, laryngeal and pharyngeal epithelial cells exhibit 100-fold greater sensitivity than esophageal epithelial cells [74]. Long-term pepsin stimulation may cause cancerous transformation of laryngeal mucosal epithelial cells $[17,23]$. Pepsin expression has been reported to be elevated in laryngeal and hypopharyngeal malignant tumor tissues $[17,23,69]$.

Sereg-Bahar et al. [23] reported that total pepsin and bile acid levels were higher in saliva samples from 30 patients with laryngeal cancer than in saliva samples from 34 healthy controls. Niu et al. [69] reported that 70 patients with primary hypopharyngeal carcinomas showed higher levels of pepsin expression than controls, based on IHC analysis. They also found that higher pepsin levels were associated with nodal metastasis. Therefore, pepsin may not only be involved in the occurrence of tumors, but might also play a role in lymph node metastasis of hypopharyngeal carcinoma

As presented in Fig. 1, taken together, these observations imply that chronic exposure to pepsin promotes the development of laryngeal and hypopharyngeal cancers. However, the actual mechanism underlying the link between pepsin and the occurrence and development of laryngeal and hypopharyngeal cancers remains unclear. Several possible mechanisms are discussed below.

\section{DAMAGETO LARYNGEAL EPITHELIAL CELLS BY PEPSIN}

\section{Activated pepsin disrupts intercellular adhesion and ligation, affecting the function of epithelial cells}

Hydrochloric acid converts the pepsinogen secreted by the chief cells of the stomach to active pepsin, which digests proteins by hydrolyzing peptide bonds. Piper and Fenton [75] demonstrated digestive activity in crude gastric juice using the radioiodinated serum albumin method. They reported that pepsin was active at $\mathrm{pH} 2.0$ and inactive at $\mathrm{pH}$ 6.5. Of note, although pepsin is inactive at $\mathrm{pH} 6.5$, it remains stable; it can be reactivated by a reduction to $\mathrm{pH} 2.0$, and shows retention of $70 \%$ of its original activity [52]. When acid reflux occurs, pepsin adhering to the cell membrane is activated by the resultant reduction in laryngeal 


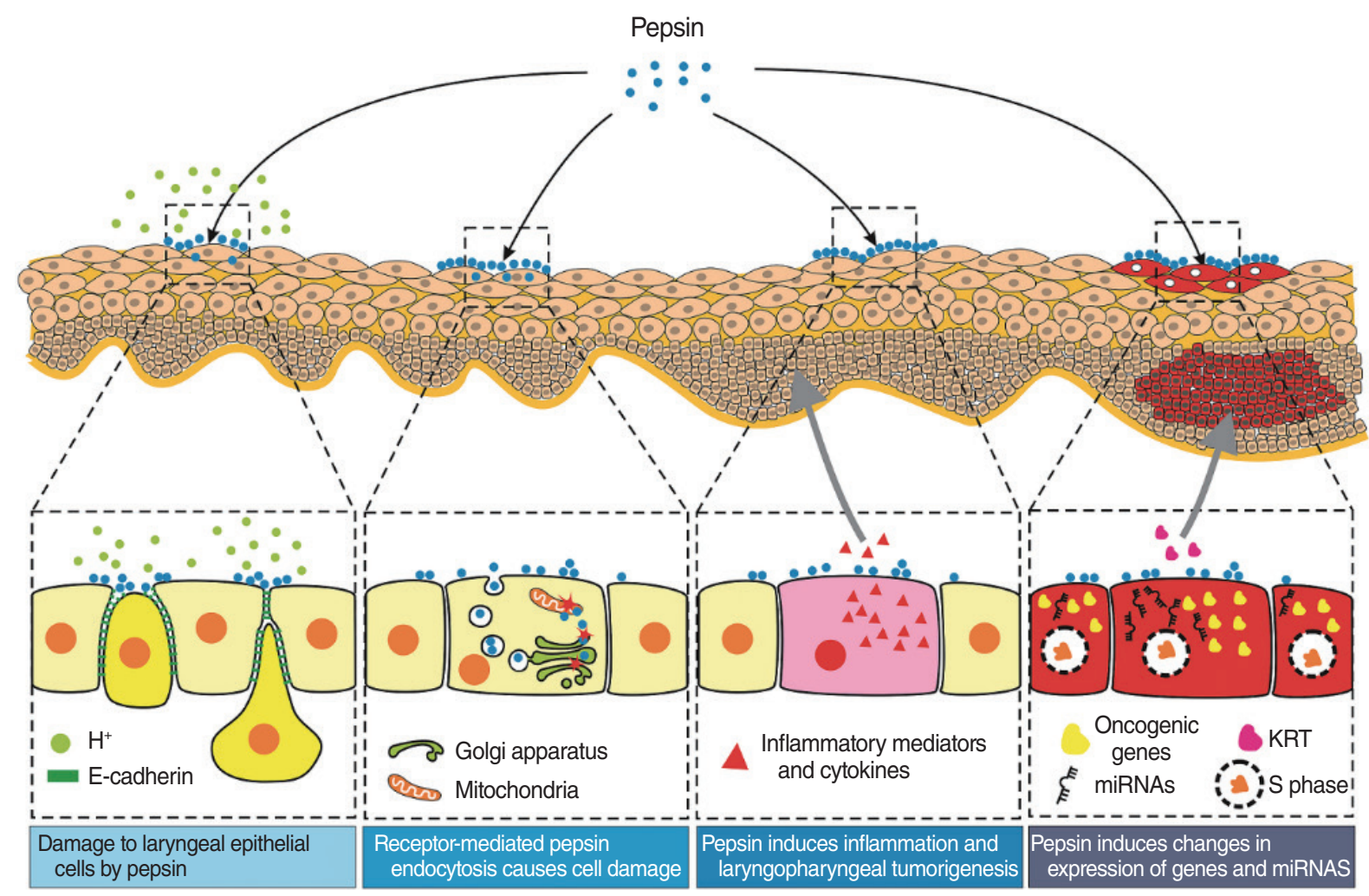

Fig. 1. Diagram illustrating the role of pepsin in laryngeal and hypopharyngeal epithelial damage and tumorigenesis. $\mathrm{H}^{+}$, hydrogen; miRNA, microRNA; KRT, keratin.

$\mathrm{pH}$. Activated pepsin disrupts the barrier function of the epithelium by interfering with intercellular connections (gap junctions) [76-78]. Cadherins are type 1 transmembrane proteins that act as cell adhesion molecules and play a crucial role in the formation of adhesion junctions to bind cells to each other. The adhesion between cells in tissues or organs is mainly mediated by the extracellular domain of cadherin, which binds to adapters and signaling proteins, collectively referred to as cadherin adhesion proteins [79].

E-cadherin is a type of cadherin expressed in epithelial tissue, which plays an important structural role in tissues and organs. Downregulation of the expression of this protein may reduce the adhesion function of cells, thereby increasing the possibility of tumor cell infiltration and metastasis $[80,81]$. E-cadherin inhibits invasion and metastasis and is regarded as a tumor suppressor [82]. Reichel et al. [80] performed 24-hour $\mathrm{pH}$ monitoring in 21 patients following laryngectomy to determine the occurrence of LPRD, and used IHC to assess E-cadherin expression in the collected paraffin-embedded laryngeal biopsy specimens. They found a significant reduction in E-cadherin expression in the hypopharyngeal tissue of patients with LPRD. Tan et al. [17] used IHC to analyze the expression patterns of pepsin and other related proteins in 87 patients with laryngeal carcinoma. They found that pepsin expression was positively correlated with vimentin and $\beta$-catenin expression, but was negatively cor- related with E-cadherin expression. These observations indicated that high laryngeal pepsin expression may directly affect E-cadherin expression. Tan et al. [17] also reported that in laryngeal carcinoma Hep-2 and Tu212 cells, increased pepsin levels significantly reduced the expression of E-cadherin and increased expression levels of the mesenchymal markers vimentin and $\beta$-catenin, implying that increased pepsin levels could result in induction of the epithelial-mesenchymal transition in laryngeal carcinoma.

Consumption and destruction of the epithelial defense barrier, causing laryngeal mucosal epithelial damage

There is a significant correlation between pepsin and the depletion of laryngeal protective proteins (carbonic anhydrase isoenzyme III [CA III] and Sep 70). In vitro studies showed that exposure of the mucosa to pepsin, rather than gastric acid alone, reduced CA III and Sep70 protein levels [83,84]. Samuels et al. [85] suggested that pepsin inhibits the expression of laryngeal protective proteins, such as mucins $2,3,5 \mathrm{AC}, 5 \mathrm{~B}$, and 12 , thereby aggravating damage to the laryngeal mucosa by gastric acid. Irreversible inhibition of pepsin by pepsin inhibitors has been reported to prevent depletion of CA III and Sep 70 in a porcine larynx culture model in vitro [83]. Therefore, pepsin may be directly responsible for the depletion of laryngeal protective proteins. 
It has been suggested that CA III catalyzes the reversible hydration of $\mathrm{CO}_{2}$ to produce bicarbonate ions [86-88], thereby facilitating local alkalinization of the microenvironment, inhibiting pepsin activity, and protecting the upper airway mucosa $[38,72$, 89]. Furthermore, the enzyme has two highly reactive cysteines on its surface (Cys183 and Cys188), which form a disulfide bond in vivo [90]. These highly reactive cysteines protect against oxidative stress under stressful conditions or in pathological conditions [91]. CA III may play an important role in epithelial defense in the upper digestive tract [91]. Thus, depletion of expression of CA III induced by pepsin may be a potential pathophysiologic mechanism for carcinogenesis in the laryngopharynx.

Heat shock proteins or stress proteins are highly conserved and widely expressed cellular defense molecules. These stressinduced proteins are presumed to act as molecular chaperones by regulating the proper folding and unfolding of proteins and their transport within cells [92]. Therefore, stress proteins protect cellular proteins from damage and increase epithelial cell tolerance to lethal levels of damage by participating in the repair and removal of damaged polypeptides [93,94]. Johnston et al. [83] suggested that Sep70 expression is normally induced under acidic conditions, whereas levels of Sep70 are significantly reduced in the presence of pepsin. This stress protein response may lead to tissue damage and changes in the cytokine environment that contribute to the development of laryngopharyngeal malignancy.

\section{Receptor-mediated pepsin endocytosis causes cell damage}

As mentioned above, Piper and Fenton [75] pointed out that pepsin activity showed a curve correlation with the $\mathrm{pH}$ change in the local environment. Some studies showed that pepsin can enter cells through receptor-mediated endocytosis and then be stored in vesicles and transported to other complex organelles (such as the Golgi apparatus). It had been demonstrated that pepsin ingested by cells in the larynx remains intact within the cells $[83,95,96]$. The pepsin absorbed by receptor-mediated endocytosis of the laryngeal epithelium is inactive or dormant because the mean $\mathrm{pH}$ of the laryngopharynx is $6.8[83,95,96]$. Importantly, pepsin is stable under this condition. Thus, pepsin could be reactivated by a decrease in $\mathrm{pH}$ even if the reflux event is weak or non-acidic. The reactivated pepsin could cause damage to laryngopharyngeal cells.

\section{Pepsin induces inflammation and laryngopharyngeal tumorigenesis}

Long-term reflux stimulation has been reported to cause damage and structural changes in the laryngopharyngeal mucosa, leading to chronic inflammation, which is an important cause of laryngopharyngeal carcinoma caused by LPR [10]. Non-acid pepsin may destroy laryngopharyngeal mucosal cells by receptor-mediated endocytosis and increase the expression levels of inflammatory mediators and cytokines in a manner similar to that in the esophageal mucosa of patients with reflux esophagitis. This suggests that pepsin may independently induce mucosal inflammation by being endocytosed into cells and activated [92]. Samuels et al. [97] demonstrated that pepsin upregulated the expression of inflammatory cytokines interleukin (IL)-8, IL1F10, IL-1A, and IL-5, as well as the chemokine CXCL14, its receptor CCR6, and its ligands CCL20 and CCL26; these changes may cause hypopharyngeal mucosal injury. In laryngeal carcinoma cells, pepsin was shown to induce the epithelial-mesenchymal transition via the IL-8 signaling pathway [17].

Tumorigenic transformation of the laryngeal epithelial mucosa increases the risk of laryngopharyngeal cancer, which may play an important role in progression from precancerous lesions to malignant transformation.

\section{Pepsin induces changes in expression of laryngeal and hypopharyngeal genes and microRNAs}

Gastroesophageal reflux causes metaplastic changes in the esophagus (e.g., Barrett's esophagus) that increase the risk of esophageal adenocarcinoma [98]. The laryngeal mucosa is considered more sensitive to gastric reflux than is the esophageal mucosa. Johnston et al. [52] examined the effects of pepsin exposure on the expression of 84 oncogenic genes in human hypopharyngeal squamous cell carcinoma FaDu cells; they found $>1.5$-fold increases in the expression levels of three genes (CASP8, FADDlike apoptosis regulator, and V-ets erythrocytosis virus E26 oncogene homolog 2) and $>1.5$-fold reductions in the expression levels of 24 tumor suppressor genes (including, most notably, Vakt mouse thymoma virus oncogene homolog 1 gene, BCL2-related cell death agonist gene, and BCL2-related X protein gene). Histological metaplasia is a complex process, and many biomarkers in the laryngeal and pharyngeal mucosae are stimulated by repeated pepsin exposure, such as the mucosal defense markers E-cadherin, MUC2, and MUC5B; the squamous/columnar marker KRT14; and the inflammatory markers CD1d, CRNN, and transforming growth factor-1 [99]. Studies have shown that the laryngeal and pharyngeal mucosae mainly comprise columnar epithelium in individuals without LPR, while LPR is associated with increased squamous epithelium marker expression [54,100].

Johnston et al. [52] reported that exposure to pepsin caused laryngeal epithelial cells to exhibit significant alterations in the expression levels of certain microRNA (miRNAs), including upregulation of miR-130a, miR-141, miR-15a, miR-185, miR-222, miR-29b, miR-32, miR-423-3p, and miR-423-5p, as well as downregulation of let-7a, let-7b, let-7c, let-7e, and miR-128. The members of the let miRNA family were significantly dysregulated in laryngeal epithelial cells exposed to non-acidic pepsin, and showed a corresponding increase in the expression of their target oncoprotein Ras [52]. Increased Ras expression has been found to be associated with increased cell proliferation, and dysregulation of Ras expression has been observed in laryngeal carcinoma [101]. 


\section{PEPSIN AS A POTENTIAL THERAPEUTIC TARGET FOR PREVENTION AND TREATMENT OF LARYNGEAL AND HYPOPHARYNGEAL CARCINOMAS}

PPIs have been widely used to treat LPR; they are responsible for the consumption of a great deal of medical resources and incur significant economic costs [102]. However, multichannel intracavity impedance and $\mathrm{pH}$ monitoring have revealed that PPIs cannot achieve satisfactory results in the treatment of LPR [103]. Moreover, multiple randomized controlled clinical trials have shown that the use of PPIs in reflux diseases is of limited benefit [104-106]. A meta-analysis that included 5712 Barrett's esophagus patients also found that PPIs had no dysplasia-protective effects [107]. Of note, Samuels et al. [108] found a positive correlation between the use of PPIs and the occurrence of esophageal adenocarcinoma, as did many other studies, including a nationwide study from Denmark in which long-term use of PPIs was associated with an increased risk of high-grade dysplasia or carcinogenesis of the esophagus [109]. Using endoscopy, Nason et al. [110] revealed that patients who took PPIs were more likely to suffer esophageal adenocarcinogenesis. One study found that long-term use of PPIs did not affect cyclooxygenase-2 (COX-2) expression, whereas nonacid pepsin negatively affected COX-2 expression [111].This finding implies that it is nonacid materials, rather than acid, that play important roles in reflux diseases.

PPIs can reduce heartburn, but they also increase pepsin concentrations in reflux fluid. Ten Kate et al. [112] discovered that omeprazole inhibited secretion of acid, but not pepsin secretion, thereby increasing the relative concentration of pepsin. A recent in vitro study indicated that acid alone did not disrupt barrier integrity, whereas high concentrations of pepsin elicited barrier disruption and neutrophil trans-epithelial migration [113]. Walentek et al. [114] found that long-term use of PPIs could lead to prolonged laryngeal exposure to weakly acidic and non-acid reflux contents that damaged mucosal regeneration. In summary, treatment with PPIs may increase pepsin concentrations and aggravate reflux diseases. Thus, as a key marker of non-acid reflux contents, pepsin may play an important role in laryngeal and hypopharyngeal epithelial inflammation and carcinogenesis.

Pepsin is currently presumed to be taken up by laryngeal epithelial cells via receptor-mediated endocytosis and to be activated in organelles, thereby resulting in cell damage [95]. These effects lead to tumor-like transformation, increasing the risk of laryngeal cancer. New therapeutic approaches targeting pepsin have been proposed, including the use of irreversible pepsin inhibitors and/or pepsin receptor antagonists $[95,115,116]$. Johnston et al. [115] suggested a mechanism of targeting pepsin to treat LPRD: (1) establish an irreversibly inactivated enzyme by inhibiting it from becoming activated pepsin inside the transreticular Golgi and late endosomes, and (2) inhibiting receptormediated uptake of pepsin via a receptor antagonist. In view of the unsatisfactory effect of PPIs, therefore, there is an urgent need to develop a new therapeutic for LPR which specifically targets pepsin [115]. In vitro studies have confirmed that Gaviscon Advance, an alginate suspension, specifically removed pepsin and bile acids from the reflux fluid, thereby inhibiting pepsin [117]. Several clinical experiments have verified the efficacy of Gaviscon Advance in reflux diseases [118-120]. Some phytochemicals (curcumin, ecabet sodium, and black-raspberry) can significantly inhibit pepsin-mediated cell damage, thus suggesting a new therapeutic strategy via adjunctive therapy with phytochemicals [121]. In addition, Johnston et al. [95] used wortmannin, an inhibitor of receptor-mediated endocytosis, to inhibit the absorption of pepsin by epithelial cells, indicating that inhibition of receptor-mediated endocytosis could be a novel therapeutic strategy in reflux disease. However, few studies have explored new therapeutic targets for pepsin.

\section{CONCLUSION}

Pepsin is a diagnostic marker of LPR. Many studies have demonstrated that pepsin promotes the development of laryngeal and hypopharyngeal cancers. The mechanisms may include: disruption of intercellular adhesion and ligation by activated pepsin, affecting the function of epithelial cells; consumption and destruction of the epithelial defense barrier, causing laryngeal mucosal epithelial damage; receptor-mediated pepsin endocytosis causing cell damage; and pepsin-induced inflammation and laryngopharyngeal tumorigenesis. Pepsin induces changes in expression of laryngeal and hypopharyngeal genes and miRNAs.

\section{CONFLICT OF INTEREST}

No potential conflict of interest relevant to this article was reported.

\section{ACKNOWLEDGMENTS}

This research was supported by National Natural Science Foundation of China (No. 81372903), and Science and Technology Department of Zhejiang Province, China (No. 2016C33144).

\section{ORCID}

Cheng-Yi Yin Sha-Sha Zhang Jiang-Tao Zhong Shui-Hong Zhou https://orcid.org/0000-0002-7103-2902 https://orcid.org/0000-0001-9895-9751 https://orcid.org/0000-0002-5989-8340 https://orcid.org/0000-0002-7163-2289 


\section{AUTHOR CONTRIBUTIONS}

Conceptualization: CYY, SSZ, SHZ. Formal analysis: JTZ. Funding acquisition: SHZ. Writing-original draft: CYY. Writing-review \& editing: SHZ.

\section{REFERENCES}

1. Bates JE, Morris CG, Hitchcock KE, Dziegielewski PT, Mendenhall WM, Amdur RJ. Locally advanced hypopharyngeal and laryngeal cancer: influence of HPV status. Radiother Oncol. 2019 Nov;140: 6-9.

2. Acuna G, Goma M,Temprana-Salvador J, Garcia-Bragado F,Alos L, Ordi J, et al. Human papillomavirus in laryngeal and hypopharyngeal lymphoepithelial carcinoma. Mod Pathol. 2019 May;32(5): 621-6.

3. Du E, Mazul AL, Farquhar D, Brennan P, Anantharaman D, AbediArdekani B, et al. Long-term survival in head and neck cancer: impact of site, stage, smoking, and human papillomavirus status. Laryngoscope. 2019 Nov;129(11):2506-13.

4. Marur S, Forastiere AA. Head and neck squamous cell carcinoma: update on epidemiology, diagnosis, and treatment. Mayo Clin Proc. 2016 Mar;91(3):386-96.

5. Alam MS, Siddiqui SA, Perween R. Epidemiological profile of head and neck cancer patients in Western Uttar Pradesh and analysis of distributions of risk factors in relation to site of tumor. J Cancer Res Ther. 2017 Jul-Sep;13(3):430-5.

6. Faggons CE, Mabedi C, Shores CG, Gopal S. Review: head and neck squamous cell carcinoma in sub-Saharan Africa. Malawi Med J. 2015 Sep;27(3):79-87.

7. Rooper LM, Windon MJ, Hernandez T, Miles B, Ha PK, Ryan WR, et al. HPV-positive squamous cell carcinoma of the larynx, oral cavity, and hypopharynx: clinicopathologic characterization with recognition of a novel warty variant. Am J Surg Pathol. 2020 May; 44(5):691-702.

8. Nurgalieva ZZ, Graham DY, Dahlstrom KR, Wei Q, Sturgis EM. A pilot study of Helicobacter pylori infection and risk of laryngopharyngeal cancer. Head Neck. 2005 Jan;27(1):22-7.

9. Lechien JR, Saussez S, Harmegnies B, Finck C, Burns JA. Laryngopharyngeal reflux and voice disorders: a multifactorial model of etiology and pathophysiology. JVoice. 2017 Nov;31(6):733-52.

10. Wilson JA. What is the evidence that gastroesophageal reflux is involved in the etiology of laryngeal cancer? Curr Opin Otolaryngol Head Neck Surg. 2005 Apr;13(2):97-100.

11. Shimazu R, Kuratomi Y, Aoki S, Inokuchi A. Laryngeal granuloma in experimental rats with gastroesophageal reflux disease and mechanically injured vocal cord mucosa. Ann Otol Rhinol Laryngol. 2014 Apr;123(4):247-51.

12. Sasaki CT, Issaeva N, Vageli DP. In vitro model for gastroduodenal reflux-induced nuclear factor-kappaB activation and its role in hypopharyngeal carcinogenesis. Head Neck. 2016 Apr;38 Suppl 1: E1381-91.

13. GtariW, Bey H, Aschi A, Bitri L, OthmanT. Impact of macromolecular crowding on structure and properties of pepsin and trypsin. Mater Sci Eng C Mater Biol Appl. 2017 Mar;72:98-105.

14. Wight R, Paleri V, Arullendran P. Current theories for the development of nonsmoking and nondrinking laryngeal carcinoma. Curr Opin Otolaryngol Head Neck Surg. 2003 Apr;11(2):73-7.

15. Copper MP, Smit CF, Stanojcic LD, Devriese PP, Schouwenburg PF, Mathus-Vliegen LM. High incidence of laryngopharyngeal reflux in patients with head and neck cancer. Laryngoscope. 2000
Jun;110(6):1007-11.

16. Galli J, Cammarota G, Calo L, Agostino S, D’Ugo D, Cianci R, et al. The role of acid and alkaline reflux in laryngeal squamous cell carcinoma. Laryngoscope. 2002 Oct;112(10):1861-5.

17. Tan JJ, Wang L, Mo TT, Wang J,Wang MG, Li XP. Pepsin promotes IL-8 signaling-induced epithelial-mesenchymal transition in laryngeal carcinoma. Cancer Cell Int. 2019 Mar;19:64.

18. Anis MM, Razavi MM, Xiao X, Soliman AM.Association of gastroesophageal reflux disease and laryngeal cancer. World J Otorhinolaryngol Head Neck Surg. 2018 Apr;4(4):278-81.

19. Riley CA, Marino MJ, Hsieh MC, Wu EL, Wu XC, McCoul ED. Detection of laryngeal carcinoma in the U.S. elderly population with gastroesophageal reflux disease. Head Neck. 2019 May;41(5): 1434-40.

20. Parsel SM, Wu EL, Riley CA, McCoul ED. Gastroesophageal and laryngopharyngeal reflux associated with laryngeal malignancy: a systematic review and meta-analysis. Clin Gastroenterol Hepatol. 2019 Jun;17(7):1253-64.

21. Busch EL, Zevallos JP, Olshan AF. Gastroesophageal reflux disease and odds of head and neck squamous cell carcinoma in North Carolina. Laryngoscope. 2016 May;126(5):1091-6.

22. LeBlanc B, Lewis E, Caldito G, Nathan CA. Increased pharyngeal reflux in patients treated for laryngeal cancer: a pilot study. Otolaryngol Head Neck Surg. 2015 Nov;153(5):791-4.

23. Sereg-Bahar M, Jerin A, Hocevar-Boltezar I. Higher levels of total pepsin and bile acids in the saliva as a possible risk factor for early laryngeal cancer. Radiol Oncol. 2015 Mar;49(1):59-64.

24. Zhang D, Zhou J, Chen B, Zhou L, Tao L. Gastroesophageal reflux and carcinoma of larynx or pharynx: a meta-analysis. Acta Otolaryngol. 2014 Oct;134(10):982-9.

25. Coca-Pelaz A, Rodrigo JP,Takes RP, Silver CE, Paccagnella D, Rinaldo A, et al. Relationship between reflux and laryngeal cancer. Head Neck. 2013 Dec;35(12):1814-8.

26. Langevin SM, Michaud DS, Marsit CJ, Nelson HH, Birnbaum AE, Eliot M, et al. Gastric reflux is an independent risk factor for laryngopharyngeal carcinoma. Cancer Epidemiol Biomarkers Prev. 2013 Jun;22(6):1061-8.

27. Tae K, Jin BJ, Ji YB, Jeong JH, Cho SH, Lee SH. The role of laryngopharyngeal reflux as a risk factor in laryngeal cancer: a preliminary report. Clin Exp Otorhinolaryngol. 2011 Jun;4(2):101-4.

28. Basseri B, Conklin JL, Mertens RB, Lo SK, Bellack GS, Shaye OA. Heterotopic gastric mucosa (inlet patch) in a patient with laryngopharyngeal reflux (LPR) and laryngeal carcinoma: a case report and review of literature. Dis Esophagus. 2009;22(4):E1-5.

29. Ozlugedik S, Yorulmaz I, Gokcan K. Is laryngopharyngeal reflux an important risk factor in the development of laryngeal carcinoma? Eur Arch Otorhinolaryngol. 2006 Apr;263(4):339-43.

30. Geterud A, Bove M, Ruth M. Hypopharyngeal acid exposure: an independent risk factor for laryngeal cancer? Laryngoscope. 2003 Dec;113(12):2201-5.

31. Nilsson M, Chow WH, Lindblad M, Ye W. No association between gastroesophageal reflux and cancers of the larynx and pharynx. Cancer Epidemiol Biomarkers Prev. 2005 May;14(5):1194-7.

32. Smit CF, Copper MP, van Leeuwen JA, Schoots IG, Stanojcic LD. Effect of cigarette smoking on gastropharyngeal and gastroesophageal reflux.Ann Otol Rhinol Laryngol. 2001 Feb;110(2):190-3.

33. Francis DO, Maynard C, Weymuller EA, Reiber G, Merati AL, Yueh B. Reevaluation of gastroesophageal reflux disease as a risk factor for laryngeal cancer. Laryngoscope. 2011 Jan;121(1):102-5.

34. Qadeer MA, Colabianchi N, Strome M,Vaezi MF. Gastroesophageal reflux and laryngeal cancer: causation or association? A critical review.Am J Otolaryngol. 2006 Mar-Apr;27(2):119-28.

35. El-Serag HB, Hepworth EJ, Lee P, Sonnenberg A. Gastroesophageal reflux disease is a risk factor for laryngeal and pharyngeal can- 
cer.Am J Gastroenterol. 2001 Jul;96(7):2013-8.

36. Kim SY, Park B, Lim H, Kim M, Kong IG, Choi HG. Increased risk of larynx cancer in patients with gastroesophageal reflux disease from a national sample cohort. Clin Otolaryngol. 2019 Jul;44(4): 534-40.

37. Best AR, Halum SL, Parker NP. Current indications for transnasal esophagoscopy: an american broncho-esophagological association survey. Ann Otol Rhinol Laryngol. 2018 Dec;127(12):926-30.

38. Chung EJ, Rho YS, Jung KY, Kim JW, Lee SW. The role of transnasal esophagoscopy in ENT office: a prospective, multicenter study in Korea. Clin Exp Otorhinolaryngol. 2014 Jun;7(2):123-5.

39. Velanovich V. Endoscopic, endoluminal fundoplication for gastroesophageal reflux disease: initial experience and lessons learned. Surgery. 2010 Oct;148(4):646-53.

40. Doustmohammadian N, Naderpour M, Khoshbaten M, Doustmohammadian $\mathrm{A}$. Is there any association between esophagogastric endoscopic findings and laryngeal cancer? Am J Otolaryngol. 2011 Nov-Dec;32(6):490-3.

41. Maldhure S, Chandrasekharan R, Dutta AK, Chacko A, Kurien M. Role of PH monitoring in laryngopharyngeal reflux patients with voice disorders. Iran J Otorhinolaryngol. 2016 Nov;28(89):377-83.

42. Mosli M,Alkhathlan B,Abumohssin A, Merdad M,Alherabi A, Marglani $\mathrm{O}$, et al. Prevalence and clinical predictors of LPR among patients diagnosed with GERD according to the reflux symptom index questionnaire. Saudi J Gastroenterol. 2018 Jul-Aug;24(4): 236-41.

43. Lechien JR, Bobin F, Muls V, Thill MP, Horoi M, Ostermann K, et al. Validity and reliability of the reflux symptom score. Laryngoscope. 2020 Mar;130(3):E98-107.

44. Lechien JR, Rodriguez Ruiz A, Dequanter D, Bobin F, Mouawad F, Muls V, et al. Validity and reliability of the reflux sign assessment. Ann Otol Rhinol Laryngol. 2020 Apr;129(4):313-25.

45. Lechien JR, Akst LM, Hamdan AL, Schindler A, Karkos PD, Barillari MR, et al. Evaluation and management of laryngopharyngeal reflux disease: state of the art review. Otolaryngol Head Neck Surg. 2019 May;160(5):762-82.

46. Hammer HF. Reflux-associated laryngitis and laryngopharyngeal reflux: a gastroenterologist's point of view. Dig Dis. 2009;27(1): 14-7.

47. Ford CN. Evaluation and management of laryngopharyngeal reflux. JAMA. 2005 Sep;294(12):1534-40.

48. Hanson DG, Conley D, Jiang J, Kahrilas P. Role of esophageal pH recording in management of chronic laryngitis: an overview. Ann Otol Rhinol Laryngol Suppl. 2000 Oct;184:4-9.

49. Postma GN. Ambulatory pH monitoring methodology. Ann Otol Rhinol Laryngol Suppl. 2000 Oct;184:10-4.

50. Hayat JO, Gabieta-Somnez S, Yazaki E, Kang JY,Woodcock A, Dettmar P, et al. Pepsin in saliva for the diagnosis of gastro-oesophageal reflux disease. Gut. 2015 Mar;64(3):373-80.

51. Na SY, Kwon OE, Lee YC, Eun YG. Optimal timing of saliva collection to detect pepsin in patients with laryngopharyngeal reflux. Laryngoscope. 2016 Dec;126(12):2770-3.

52. Johnston N, Yan JC, Hoekzema CR, Samuels TL, Stoner GD, Blumin JH, et al. Pepsin promotes proliferation of laryngeal and pharyngeal epithelial cells. Laryngoscope. 2012 Jun;122(6):1317-25.

53. Dy F, Amirault J, Mitchell PD, Rosen R. Salivary pepsin lacks sensitivity as a diagnostic tool to evaluate extraesophageal reflux disease. J Pediatr. 2016 Oct;177:53-8.

54. Hayat JO, Yazaki E, Moore AT, Hicklin L, Dettmar P, Kang JY, et al. Objective detection of esophagopharyngeal reflux in patients with hoarseness and endoscopic signs of laryngeal inflammation. J Clin Gastroenterol. 2014 Apr;48(4):318-27.

55. Yadlapati R,Adkins C, Jaiyeola DM, Lidder AK, Gawron AJ,Tan BK, et al.Abilities of oropharyngeal $\mathrm{pH}$ tests and salivary pepsin analy- sis to discriminate between asymptomatic volunteers and subjects with symptoms of laryngeal irritation. Clin Gastroenterol Hepatol. 2016 Apr;14(4):535-42.

56. Raja Nhari RM, Muhammad Zailani AN, Khairil Mokhtar NF, Hanish I. Detection of porcine pepsin in model cheese using polyclonal antibody-based ELISA. Food Addit Contam PartA Chem Anal Control Expo Risk Assess. 2020 Apr;37(4):561-7.

57. Ju H, Liu X, Zhang G, Liu D, Yang Y. Comparison of the structural characteristics of native collagen fibrils derived from bovine tendons using two different methods: modified acid-solubilized and pepsin-aided extraction. Materials (Basel). 2020 Jan;13(2):358.

58. Fortunato JE, D'Agostino RB Jr, Lively MO. Pepsin in saliva as a biomarker for oropharyngeal reflux compared with 24-hour esophageal impedance/pH monitoring in pediatric patients. Neurogastroenterol Motil. 2017 Feb;29(2):e12936.

59. Lee YJ, Kwon J, Shin S, Eun YG, Shin JH, Lee GJ. Optimization of saliva collection and immunochromatographic detection of salivary pepsin for point-of-care testing of laryngopharyngeal reflux. Sensors (Basel). 2020 Jan;20(1):325.

60. Sereg-Bahar M, Jerin A, Jansa R, Stabuc B, Hocevar-Boltezar I. Pepsin and bile acids in saliva in patients with laryngopharyngeal reflux: a prospective comparative study. Clin Otolaryngol. 2015 Jun;40(3):234-9.

61. Guo Z, Wu H, Jiang J, Zhang C. Pepsin in saliva as a diagnostic marker for gastroesophageal reflux disease: a meta-analysis. Med Sci Monit. 2018 Dec;24:9509-16.

62. Du X,Wang F, Hu Z, Wu J, Wang Z, Yan C, et al. The diagnostic value of pepsin detection in saliva for gastro-esophageal reflux disease: a preliminary study from China. BMC Gastroenterol. 2017 Oct;17(1):107.

63. Formanek M, Jancatova D, Kominek P, Tomanova R, Zelenik K. Comparison of impedance and pepsin detection in the laryngeal mucosa to determine impedance values that indicate pathological laryngopharyngeal reflux. Clin Transl Gastroenterol. 2017 Oct; 8(10):e123.

64. Jiang A, Liang M, Su Z, Chai L, Lei W, Wang Z, et al. Immunohistochemical detection of pepsin in laryngeal mucosa for diagnosing laryngopharyngeal reflux. Laryngoscope. 2011 Jul;121(7):1426-30.

65. Johnston N, Knight J, Dettmar PW, Lively MO, Koufman J. Pepsin and carbonic anhydrase isoenzyme III as diagnostic markers for laryngopharyngeal reflux disease. Laryngoscope. 2004 Dec;114(12): 2129-34.

66. Komatsu Y, Kelly LA, Zaidi AH, Rotoloni CL, Kosovec JE, Lloyd EJ, et al. Hypopharyngeal pepsin and Sep70 as diagnostic markers of laryngopharyngeal reflux: preliminary study. Surg Endosc. 2015 May;29(5):1080-7.

67. Saritas Yuksel E, Hong SK, Strugala V, Slaughter JC, Goutte M, Garrett CG, et al. Rapid salivary pepsin test: blinded assessment of test performance in gastroesophageal reflux disease. Laryngoscope. 2012 Jun;122(6):1312-6.

68. Knight J, Lively MO, Johnston N, Dettmar PW, Koufman JA. Sensitive pepsin immunoassay for detection of laryngopharyngeal reflux. Laryngoscope. 2005 Aug;115(8):1473-8.

69. Niu K, Guo C, Teng S, Zhou D, Yu S, Yin W, et al. Pepsin promotes laryngopharyngeal neoplasia by modulating signaling pathways to induce cell proliferation. PLoS One. 2020 Jan;15(1):e0227408.

70. Sasaki CT, Doukas SG, Costa J,Vageli DP. Biliary reflux as a causal factor in hypopharyngeal carcinoma: new clinical evidence and implications. Cancer. 2019 Oct;125(20):3554-65.

71. Doukas SG, Cardoso B, Tower JI, Vageli DP, Sasaki CT. Biliary tumorigenic effect on hypopharyngeal cells is significantly enhanced by $\mathrm{pH}$ reduction. Cancer Med. 2019 Aug;8(9):4417-27.

72. Koufman JA. The otolaryngologic manifestations of gastroesophageal reflux disease (GERD): a clinical investigation of 225 patients 
using ambulatory 24-hour $\mathrm{pH}$ monitoring and an experimental investigation of the role of acid and pepsin in the development of laryngeal injury. Laryngoscope. 1991Apr;101(4 Pt 2 Suppl 53):1-78.

73. Sharma N, Agrawal A, Freeman J,Vela MF, Castell D. An analysis of persistent symptoms in acid-suppressed patients undergoing impedance-pH monitoring. Clin Gastroenterol Hepatol. 2008 May;6(5): 521-4.

74. Koufman JA. Laryngopharyngeal reflux is different from classic gastroesophageal reflux disease. Ear Nose Throat J. 2002 Sep;81(9 Suppl 2):7-9.

75. Piper DW, Fenton BH. pH stability and activity curves of pepsin with special reference to their clinical importance. Gut. 1965 Oct; 6(5):506-8.

76. Tutuian R,Vela MF, Hill EG, Mainie I, Agrawal A, Castell DO. Characteristics of symptomatic reflux episodes on acid suppressive therapy.Am J Gastroenterol. 2008 May;103(5):1090-6.

77. Poelmans J,Tack J, Feenstra L. Paroxysmal laryngospasm: a typical but underrecognized supraesophageal manifestation of gastroesophageal reflux? Dig Dis Sci. 2004 Nov-Dec;49(11-12):1868-74.

78. Sifrim D, Mittal R, Fass R, Smout A, Castell D, Tack J, et al. Review article: acidity and volume of the refluxate in the genesis of gastrooesophageal reflux disease symptoms. Aliment Pharmacol Ther. 2007 May;25(9):1003-17.

79. Alimperti S, Andreadis ST. CDH2 and CDH11 act as regulators of stem cell fate decisions. Stem Cell Res. 2015 May;14(3):270-82.

80. Reichel O, Mayr D, Durst F, Berghaus A. E-cadherin but not betacatenin expression is decreased in laryngeal biopsies from patients with laryngopharyngeal reflux. Eur Arch Otorhinolaryngol. 2008 Aug;265(8):937-42.

81. Galera-Ruiz H, Rios-Moreno MJ, Gonzalez-Campora R, Ortega I, Fernandez A, Garcia-Escudero A, et al. The cadherin-catenin complex in laryngeal squamous cell carcinoma. Eur Arch Otorhinolaryngol. 2012 Apr;269(4):1183-8.

82. Takeichi M. Cadherins in cancer: implications for invasion and metastasis. Curr Opin Cell Biol. 1993 Oct;5(5):806-11.

83. Johnston N, Dettmar PW, Lively MO, Postma GN, Belafsky PC, Birchall M, et al. Effect of pepsin on laryngeal stress protein (Sep70, Sep53, and Hsp70) response: role in laryngopharyngeal reflux disease.Ann Otol Rhinol Laryngol. 2006 Jan;115(1):47-58.

84. Johnston N, Bulmer D, Gill GA, Panetti M, Ross PE, Pearson JP, et al. Cell biology of laryngeal epithelial defenses in health and disease: further studies. Ann Otol Rhinol Laryngol. 2003 Jun;112(6): 481-91.

85. Samuels TL, Handler E, Syring ML, Pajewski NM, Blumin JH, Kerschner JE, et al. Mucin gene expression in human laryngeal epithelia: effect of laryngopharyngeal reflux. Ann Otol Rhinol Laryngol. 2008 Sep;117(9):688-95.

86. Forero-Quintero LS, Ames S, Schneider HP, Thyssen A, Boone CD, Andring JT, et al. Membrane-anchored carbonic anhydrase IV interacts with monocarboxylate transporters via their chaperones CD147 and GP70. J Biol Chem. 2019 Jan;294(2):593-607.

87. Mikulski RL, Silverman DN. Proton transfer in catalysis and the role of proton shuttles in carbonic anhydrase. Biochim Biophys Acta. 2010 Feb;1804(2):422-6.

88. Tashian RE. The carbonic anhydrases: widening perspectives on their evolution, expression and function. Bioessays. 1989 Jun;10(6): 186-92.

89. Belafsky PC, Rees CJ. Laryngopharyngeal reflux: the value of otolaryngology examination. Curr Gastroenterol Rep. 2008 Jun;10(3): 278-82.

90. Kannan KK, Ramanadham M, JonesTA. Structure, refinement, and function of carbonic anhydrase isozymes: refinement of human carbonic anhydrase I. Ann NYAcad Sci. 1984;429:49-60.

91. Monti DM, De Simone G, Langella E, Supuran CT, Di Fiore A, Mon- ti SM. Insights into the role of reactive sulfhydryl groups of Carbonic Anhydrase III and VII during oxidative damage. J Enzyme Inhib Med Chem. 2017 Dec;32(1):5-12.

92. Welch WJ, Brown CR. Influence of molecular and chemical chaperones on protein folding. Cell Stress Chaperones. 1996 Jun;1(2): 109-15.

93. Wu K, Stull F, Lee C, Bardwell JC. Protein folding while chaperone bound is dependent on weak interactions. Nat Commun. 2019 Oct;10(1):4833.

94. Freilich R, ArharT, Abrams JL, Gestwicki JE. Protein-protein interactions in the molecular chaperone network. Acc Chem Res. 2018 Apr;51(4):940-9.

95. Johnston N, Wells CW, Samuels TL, Blumin JH. Rationale for targeting pepsin in the treatment of reflux disease. Ann Otol Rhinol Laryngol. 2010 Aug;119(8):547-58.

96. Johnston N, Wells CW, Blumin JH, Toohill RJ, Merati AL. Receptormediated uptake of pepsin by laryngeal epithelial cells. Ann Otol Rhinol Laryngol. 2007 Dec;116(12):934-8.

97. Samuels TL, Johnston N. Pepsin as a causal agent of inflammation during nonacidic reflux. Otolaryngol Head Neck Surg. 2009 Nov; 141(5):559-63.

98. Samuels TL, Altman KW, Gould JC, KindelT, Bosler M, MacKinnon A, et al. Esophageal pepsin and proton pump synthesis in barrett's esophagus and esophageal adenocarcinoma. Laryngoscope. 2019 Dec;129(12):2687-95.

99. Wood JM, Hussey DJ, Woods CM, Astill D, Watson DI, Lee B, et al. Does gene expression in laryngeal subsites differ between patients with laryngopharyngeal reflux and controls? Clin Otolaryngol. 2018 Feb;43(1):158-63.

100. Van Roon AH, Mayne GC, Wijnhoven BP, Watson DI, Leong MP, Neijman GE, et al. Impact of gastro-esophageal reflux on mucin mRNA expression in the esophageal mucosa. J Gastrointest Surg. 2008 Aug;12(8):1331-40.

101. Zhang F, Cao H. MicroRNA-143-3p suppresses cell growth and invasion in laryngeal squamous cell carcinoma via targeting the k-Ras/ Raf/MEK/ERK signaling pathway. Int J Oncol. 2019 Feb;54(2): 689-701.

102. Nath K, Reyaldeen R, Palamuthusingam D. Proton-pump inhibitor overuse: a cautionary tale in misguided benefit. Intern Med J. 2019 Oct;49(10):1337.

103. Delshad SD, Almario CV, Chey WD, Spiegel BM. Prevalence of gastroesophageal reflux disease and proton pump inhibitor-refractory symptoms. Gastroenterology. 2020 Apr;158(5):1250-61.

104. Eherer AJ, Habermann W, Hammer HF, Kiesler K, Friedrich G, Krejs GJ. Effect of pantoprazole on the course of reflux-associated laryngitis: a placebo-controlled double-blind crossover study. Scand J Gastroenterol. 2003 May;38(5):462-7.

105. Noordzij JP, Khidr A, Evans BA, Desper E, Mittal RK, Reibel JF, et al. Evaluation of omeprazole in the treatment of reflux laryngitis: a prospective, placebo-controlled, randomized, double-blind study. Laryngoscope. 2001 Dec;111(12):2147-51.

106. El-Serag HB, Lee P, Buchner A, Inadomi JM, Gavin M, McCarthy DM. Lansoprazole treatment of patients with chronic idiopathic laryngitis: a placebo-controlled trial. Am J Gastroenterol. 2001 Apr; 96(4):979-83.

107. Hu Q, Sun TT, Hong J, Fang JY, Xiong H, Meltzer SJ. Proton pump inhibitors do not reduce the risk of esophageal adenocarcinoma in patients with Barrett's esophagus: a systematic review and metaanalysis. PLoS One. 2017 Jan;12(1):e0169691.

108. SamuelsT, Hoekzema C, Gould J, Goldblatt M, Frelich M, Bosler M, et al. Local synthesis of pepsin in Barrett's esophagus and the role of pepsin in esophageal adenocarcinoma. Ann Otol Rhinol Laryngol. 2015 Nov;124(11):893-902.

109. Hvid-Jensen F, Pedersen L, Funch-Jensen P, Drewes AM. Proton 
pump inhibitor use may not prevent high-grade dysplasia and oesophageal adenocarcinoma in Barrett's oesophagus: a nationwide study of 9883 patients. Aliment Pharmacol Ther. 2014 May;39(9): 984-91.

110. Nason KS, Wichienkuer PP, Awais O, Schuchert MJ, Luketich JD, O'Rourke RW, et al. Gastroesophageal reflux disease symptom severity, proton pump inhibitor use, and esophageal carcinogenesis. Arch Surg. 2011 Jul;146(7):851-8.

111. Lao-Sirieix P, Roy A, Worrall C, Vowler SL, Gardiner S, Fitzgerald RC. Effect of acid suppression on molecular predictors for esophageal cancer. Cancer Epidemiol Biomarkers Prev. 2006 Feb;15(2): 288-93.

112. Ten Kate RW,Tuynman HA, Festen HP, Pals G, Meuwissen SG. Effect of high dose omeprazole on gastric pepsin secretion and serum pepsinogen levels in man. Eur J Clin Pharmacol. 1988;35(2):173-6.

113. Hurley BP, Jugo RH, Snow RF, Samuels TL, Yonker LM, Mou H, et al. Pepsin triggers neutrophil migration across acid damaged lung epithelium. Sci Rep. 2019 Sep;9(1):13778.

114. Walentek P, BeyerT, Hagenlocher C, Muller C, Feistel K, Schweickert A, et al.ATP4a is required for development and function of the Xenopus mucociliary epidermis: a potential model to study proton pump inhibitor-associated pneumonia. Dev Biol. 2015 Dec;408(2): 292-304.

115. Johnston N, Dettmar PW, Ondrey FG, Nanchal R, Lee SH, Bock JM. Pepsin: biomarker, mediator, and therapeutic target for reflux and aspiration. Ann NYAcad Sci. 2018 Dec;1434(1):282-9.

116. Bardhan KD, Strugala V, Dettmar PW. Reflux revisited: advancing the role of pepsin. Int J Otolaryngol. 2012;2012:646901.

117. Strugala V, Avis J, Jolliffe IG, Johnstone LM, Dettmar PW. The role of an alginate suspension on pepsin and bile acids: key aggressors in the gastric refluxate: does this have implications for the treatment of gastro-oesophageal reflux disease? J Pharm Pharmacol. 2009 Aug;61(8):1021-8.

118. McGlashan JA, Johnstone LM, Sykes J, Strugala V, Dettmar PW. The value of a liquid alginate suspension (Gaviscon Advance) in the management of laryngopharyngeal reflux. Eur Arch Otorhinolaryngol. 2009 Feb;266(2):243-51.

119. Reimer C, Lodrup AB, Smith G, Wilkinson J, Bytzer P. Randomised clinical trial: alginate (Gaviscon Advance) vs. placebo as add-on therapy in reflux patients with inadequate response to a once daily proton pump inhibitor. Aliment Pharmacol Ther. 2016 Apr;43(8): 899-909.

120. Wilkie MD, Fraser HM, Raja H. Gaviscon® Advance alone versus co-prescription of Gaviscon ${ }^{\circledR}$ Advance and proton pump inhibitors in the treatment of laryngopharyngeal reflux. Eur Arch Otorhinolaryngol. 2018 Oct;275(10):2515-21.

121. Samuels TL, Pearson AC, Wells CW, Stoner GD, Johnston N. Curcumin and anthocyanin inhibit pepsin-mediated cell damage and carcinogenic changes in airway epithelial cells. Ann Otol Rhinol Laryngol. 2013 Oct;122(10):632-41. 